\title{
Evaluation of Microbial and Enzyme Activity of Rhizospheric Soils under Integrated Nutrient Management of Apricot
}

\author{
M.A. Kuchay ${ }^{1}$, D.D. Sharma ${ }^{1}$ and Vijay Kumar $^{2}$ \\ ${ }^{1}$ Department of Fruit Science, ${ }^{2}$ Department of Basic Science, Dr YS Parmar University of \\ Horticulture and Forestry Nauni, Solan- 173230 (H.P), India \\ *Corresponding author
}

\section{A B S T R A C T}

\begin{tabular}{|l|}
\hline Ke y w o r d s \\
Microbial and \\
enzyme activity, \\
Rhizospheric soils, \\
Apricot
\end{tabular}

The present study was conducted at Horticultural Research and Training Station and Krishi Vigyan Kendra (HRTS \& KVK), Kandaghat, Solan, Himachal Pradesh, India. This study was done to evaluate the change in microbial and enzyme activity of rhizospheric soil by application of biofertilizers, organic and chemical fertilizers during the year 2017-18. The results showed that maximum azotobater, PSB and actinomycetes population was found significantly higher with $80 \% \mathrm{RDF}(25 \% \mathrm{CN}+75 \%$ Urea $)+20 \% \mathrm{~N}$ (VC) + (Azotobacter + PSB @ 25g/tree) during both the years of study. However, minimum was found in $100 \%$ RDF ( $100 \% \mathrm{~N}$ through $\mathrm{CN})$. Soil enzyme activities were also found significantly higher with biofertilizes in combination with organic and chemical fertilizers. Soil enzyme activities (Urease, dehydroginase and alkaline phosphotase) were observed maximum when chemical fertilizers are applied in combination with vermicompost and biofertilizers as compared to control (chemical fertilizers without vermicompost and biofertilizers). It can be concluded that application of chemical fertilizers along with organic and biofertilizers can enhance the biological properties soil.

\section{Introduction}

Nutrition plays an important role in improving productivity and quality of apricot fruits. The key to mineral nutrition is the judicious application of manures and fertilizers to the plants.

Manures and fertilizers are regularly applied in the field to meet the requirement of nutrient elements by plants. Microbial communities are important for the functioning of the ecosystem both in relations to direct interactions with plants and with regard to nutrient and organic matter cycling (Debnath et al., 2015).

Soil enzymes play key biochemical function in the overall process of organic matter decomposition in the soil system.

They are important in catalyzing several vital reactions necessary for the life process of microorganisms in soils and the stabilization of soil structure, the decomposition of organic 
wastes, organic matter formation and nutrient cycling (Das and Varma, 2011). Soil enzymatic activities have been proposed as appropriate indicators because of their intimate relationship to soil biology and rapid response to changes in nutrient management.

Dehydrogenase (DH) exists as an integral part of intact cells, involved in oxidative phosphorylation, and reflects in the total oxidative potential of the soil microbial community (Kuma et al., 2017).

Inorganic fertilizers are the chemical substances produced synthetically from inorganic products that are used to enrich soil with nutrients mostly nitrogen, phosphorus and potassium to help plants in growth and metabolic processes.

From the last two decades, inadequate and imbalanced use of inorganic fertilizers accompanied with restricted use of organic manures and bio-fertilizers has contributed considerably in raising agricultural productivity and reducing hunger worldwide.

On the other hand, they made the soils not only deficient in certain nutrients and also deteriorated the soil health (Lui and Tain, 2017).

Effect of Vermicompost promotes plant growth is well reported but mostly it is used as a main source of nitrogen and phosphorus which are nutrients as a part of some key plant structural components and act as a catalyst in the change of numerous biochemical reactions in plants and has very high porosity, aeration, drainage and water holding capacity.

Vermicompost application is one of the useful methods to renew the depleted soil fertility and augment the available pool of nutrients and conserve more water, maintain soil quality and conserve additional biological resources (Sinha, 2009). Biofertilizers contain primarily potent strain of microorganism in sufficient number. These microorganisms play a beneficial role in the soil fertility of rhizosphere and growth of plants. They are safe to handle with field application.

Their application rebalances the ratio between plant nutrients in the soil for improving crop yield and decrease the cost of some agricultural practices.

In rhizosphere soil, a large number of plant growth promoting rhizobacteria bacteria, particularly phosphate solubilizing bacteria, which have an ability to promote plant growth and increase plant production. These bacteria potentially convert insoluble $\mathrm{P}$ into an available form by release of organic acid like maleic, lactic, acetic, citric and succinic acid to dissolve insoluble $\mathrm{P}$ and other mechanism is the secretion of enzymes by PSB that are able to degrade insoluble phosphorus (Wang et al., 2017).

The present study was done with an objective to find out the effect of integrated nutrient management on microbial population and enzyme activities of soil.

\section{Materials and Methods}

A field experiment was conducted during 2017-18. The location of the experiment was in the orchard of apricot at Horticultural Research and Training Station and Krishi Vigyan Kendra (HR \& TS and KVK), Kandaghat, Solan (H.P.).

Where the field studies were conducted is located at an altitude of 1425 meters above the mean sea level, having latitude of $30.59^{\circ} \mathrm{N}$ and longitude of $77.07^{\circ} \mathrm{E}$.

The experiment was laid in Randomized Blocked Design using "New Castle" variety. A total of eleven different fertilizer combinations were made as follows: 


\begin{tabular}{|c|c|}
\hline Treatments code & Fertilizers \\
\hline $\mathrm{T}_{1 \text { (Control) }}$ & $100 \%$ RDF (100\% N through CN) \\
\hline $\mathrm{T}_{2}$ & $100 \%$ RDF (100\% N through Urea) + (Azotobacter+ PSB @ 25g/tree) \\
\hline $\mathrm{T}_{3}$ & $100 \%$ RDF (25\% CN + 75\% Urea) + (Azotobacter + PSB @ 25g/tree) \\
\hline $\mathrm{T}_{4}$ & $100 \%$ RDF (50\% CN + 50\% Urea) + ( Azotobacter +PSB @ 25g/tree) \\
\hline $\mathrm{T}_{5}$ & $100 \%$ RDF (75\% CN + 25\% Urea) + ( Azotobacter +PSB @ 25g/tree) \\
\hline $\mathrm{T}_{6}$ & $90 \% \mathrm{RDF}(25 \% \mathrm{CN}+75 \%$ Urea $)+10 \% \mathrm{~N}(\mathrm{VC})+($ Azotobacter + PSB @ 25g/tree $)$ \\
\hline $\mathrm{T}_{7}$ & $90 \% \mathrm{RDF}(50 \% \mathrm{CN}+50 \%$ Urea $)+10 \% \mathrm{~N}(\mathrm{VC})+($ Azotobacter + PSB @ 25g/tree $)$ \\
\hline $\mathrm{T}_{8}$ & $90 \% \operatorname{RDF}(75 \% \mathrm{CN}+25 \%$ Urea $)+10 \% \mathrm{~N}(\mathrm{VC})+($ Azotobacter + PSB @ 25g/tree $)$ \\
\hline $\mathrm{T}_{9}$ & $80 \% \mathrm{RDF}(25 \% \mathrm{CN}+75 \%$ Urea $)+20 \% \mathrm{~N}(\mathrm{VC})+($ Azotobacter + PSB @ 25g/tree $)$ \\
\hline $\mathrm{T}_{10}$ & $80 \%$ RDF (50\% CN + 50\% Urea) + 20\% N (VC) + (Azotobacter +PSB @ 25g/tree) \\
\hline $\mathrm{T}_{11}$ & $80 \%$ RDF $(75 \%$ CN + 25\% Urea $)+20 \% \mathrm{~N}(\mathrm{VC})+($ Azotobacter + PSB @ 25g/tree $)$ \\
\hline
\end{tabular}

*RDF (Recommended Dose of Fertilizers); (500 N: $250 \mathrm{P}_{2} \mathrm{O}_{5}: 500 \mathrm{~K}_{2} \mathrm{O}$ g/tree) + FYM- $40 \mathrm{~kg} /$ tree). CN (Calcium Nitrate); VC (Vermicompost); PSB (Phosphorus Solubilizing Bacteria)

Biofertilizer consisting of Azotobacter and PSB were used in combination with organic and inorganic fertilizers having different doses. The biofertilizer was purchased from Department of Microbiology, IARI, New Delhi, India. Plants were inoculated with charcoal based biofertilizer having $10^{-8}$ cells/ g applied @ 25g/plant.

The recommended dose of fertilizers (RDF) of apricot is $\left(500 \mathrm{~N}: 250 \mathrm{P}_{2} \mathrm{O}_{5}: 500 \mathrm{~K}_{2} \mathrm{O}\right.$ g/tree $)+$ FYM- $40 \mathrm{~kg} /$ tree). Calcium ammonium nitrate is a recommended fertilizer of apricot but this is not available in the market due to highly hygroscopic and explosive. The government of India banned to open sale, purchase and manufacturer of calcium ammonium nitrate (CAN) in the market under the explosive Act, 1884. The substitute of Calcium ammonium nitrate is calcium nitrate. The cost of calcium nitrate is $\mathrm{Rs} 48 \mathrm{~kg}^{-1}$ and the farmers cannot afford to purchase this fertilizer. So the treatments combinations were made in this experiment in such a way to get profitable yield.

Application of Single super phosphate (SSP) and muriate of potash (MOP) along with farm yard manure was applied during mid of January. Nitrogen was applied through urea and calcium nitrate in two split doses according to treatments made. First half dose was applied about two weeks before flowering and remaining half dose was applied one month after first application. Azotobacter and PSB was mixed along with $30 \mathrm{~kg}$ of vermicompost and left as such for one week for multiplication of microbes. The manures and fertilizers were broadcasting in the basin under the spread of trees, $30 \mathrm{~cm}$ away from the tree trunk and thoroughly mixed with soil.

\section{Soil microbial population assay}

Soil samples for microbial analysis were taken at a depth of $7.5 \mathrm{~cm}$ of the top soil in the rhizospheric region of plants (Ogunmwonyi et al., 2008). The enumeration of bacteria in fresh soil samples was carried out by following serial dilution plate count technique as given by Dhingra and Sinclair (2000) and Martin (1950), respectively.

\section{Soil enzyme activity assay}

Soil enzymatic activities were analysed from soil samples collected at a depth of $10 \mathrm{~cm}$ from the three different location of rhizosphere of each treatment in the month of July. We determined the activity of four enzymes, dehydrogenase, urease, acid phosphatase and alkaline phosphotase. The 
reference method for the determination of urease enzyme activities is described by (Tabatabai and Bremner, 1972). Dehydrogenase activity was assayed by quantifying the ug of TPF $(2,3,5$ - triphenyl formazan) produced and expresses as $\mathrm{g}^{-1}$ sample $\mathrm{h}^{-1}$ as described by (Casida et al., 1964). The alkaline phosphotase activity was quantifying the amount of P- nitrophenol released and expressed as ug of P-nitrophenol released $\mathrm{g}^{-1}$ sample $\mathrm{h}^{-1}$ as described by (Tabatabai and Bremner (1969).

\section{Statistical analysis}

One-way analysis of variance (ANOVA) was performed to determine the effect of different fertilizer treatments on microbial load and enzyme activity of rhizospheric soil. The level of significance referred in the results is $\mathrm{p}<$ 0.05 .

\section{Results and Discussion}

Application of $80 \%$ RDF $(25 \% \mathrm{CN}+75 \%$ Urea $)+20 \% \mathrm{~N}(\mathrm{VC})+($ Azotobacter $+\mathrm{PSB})$ resulted in maximum population $\left(20.43 \times 10^{-5}\right.$ CFU/g soil) of Azotobacter depicted in Table 1. This was statistically at par with $T_{10}$ and $\mathrm{T}_{11}$. The minimum azotobacter population $\left(17.23 \times 10^{-5} \mathrm{CFU} \mathrm{g}{ }^{-1}\right.$ soil) was found in $\mathrm{T}_{1}$ : $100 \%$ RDF (100\% N through CN) during the year 2017. In the year of 2018 , maximum azotobacter population $\left(23.33 \times 10^{-5} \mathrm{CFU} \mathrm{g}^{-1}\right.$ soil) of azotobacter was observed in $\mathrm{T}_{9}: 80 \%$ $\mathrm{RDF}(25 \% \mathrm{CN}+75 \%$ Urea $)+20 \% \mathrm{~N}(\mathrm{VC})+$ (Azotobacter + PSB) whereas minimum azotobacter population $\left(12.43 \times 10^{-5} \mathrm{CFU} \mathrm{g}^{-1}\right.$ soil) was obtained in $\mathrm{T}_{1}: 100 \% \mathrm{RDF}(100 \% \mathrm{~N}$ through $\mathrm{CN}$ ) which was statistically at par with $\mathrm{T}_{2}$.

\section{Phosphorus solubilising bacteria (PSB)}

In the year 2017, application of different source of fertilizer treatment had not shown significant difference on PSB population. During the year 2018, it is evident from the data presented in Table 1 indicated that the maximum PSB population (29.43 CFU g soil $^{-1}$ ) was noticed in treatment $\mathrm{T}_{9}: 80 \% \mathrm{RDF}$ $(25 \% \mathrm{CN}+75 \%$ Urea $)+20 \% \mathrm{~N}(\mathrm{VC})+$ (Azotobacter + PSB) which was highly significant over the other treatments, whereas minimum PSB population $\left(12.43 \mathrm{CFU} \mathrm{\textrm {g } ^ { - 1 }}\right.$ soil) was observed in treatment $\mathrm{T}_{1}: 100 \% \mathrm{RDF}$ $(100 \% \mathrm{~N}$ through $\mathrm{CN})$ which was statistically at par with $\mathrm{T}_{2}$.

Similar reports have also been given by Laishram et al., (2013) maximum azotobacter and PSB viable count were found with chemical fertilizers NPK + Vermicompost + bio-fertilizers. The increased microbial population due to application of different types of organic manures in turn provide adequate biomass as feed to microbes and helps in increasing microbial population in soil Mir et al., (2013).

The results are in conformity with those of Singh et al., (2010) who have observed that inoculation of Azotobacter, Azosprllium and PSB in strawberry seedlings increased viable count of Azotobacter and PSB over the rest of the control. Khare et al., (2018) who have found that microbial population of Azotobacter and PSB were higher in the rhizosphere of seedlings raised in microbial enriched vermicompost at the time of uprooting of plants.

Vermicomposts are rich in microbial populations and diversity, particularly fungi, bacteria and actinomycetes Edwards (1998). The increased microbial population level of biomass of the soil might be application of organic fertilizers enriched with different types of bio-fertilizers in turns provide adequate supply of nutrients for microbes and helps in increased level of microbial population in soil. 


\section{Actinomycetes}

Perusal of data presented in Table 1 showed that different treatment of INM had significant effect on actinomycetes population during both the years of study. Maximum actinomycetes population (18.27 CFU g soil $\left.{ }^{-1}\right)$ was perceived in the treatment $\mathrm{T}_{10}: 80 \% \mathrm{RDF}$ $(50 \% \mathrm{CN}+50 \%$ Urea $)+20 \% \mathrm{~N}(\mathrm{VC})+$ (Azotobacter $+\mathrm{PSB})$ which was statistically at par with $\mathrm{T}_{9}$ and minimum actinomycetes population (11.87 CFU g ${ }^{-1}$ soil) was seen in treatment $\mathrm{T}_{1}: 100 \% \mathrm{RDF}(100 \% \mathrm{~N}$ through $\mathrm{CN}$ ) which was statically at par with $\mathrm{T}_{2}$ and $\mathrm{T}_{3}$ during the year 2017.

In 2018, the maximum actinomycetes population (23.33 $\mathrm{CFU} \mathrm{g}^{-1}$ soil) was counted in $\mathrm{T}_{9} 80 \% \mathrm{RDF}(25 \% \mathrm{CN}+75 \%$ Urea $)+20 \%$ $\mathrm{N}(\mathrm{VC})+$ (Azotobacter + PSB) which was statistically at par with $\mathrm{T}_{5}, \mathrm{~T}_{6}, \mathrm{~T}_{8}, \mathrm{~T}_{10}$ and $\mathrm{T}_{11}$. Whereas the minimum actinomycetes population (14.10 CFU g ${ }^{-1}$ soil) was reported in $\mathrm{T}_{1}: 100 \% \mathrm{RDF}(100 \% \mathrm{~N}$ through $\mathrm{CN})$ which was statistically at par with $\mathrm{T}_{4}$.

Similar results were reported by Panchal et al., (2018) in wheat. Actinomycetes population were significantly higher in those treatments receiving bio-fertilizers, FYM and vermicompost. This may be attributed to the vermicompost containing higher amount of growth promoting substances, vitamins and enzymes, which in turn increased microbial population and in addition to this azotobacter + phospho solubilising bacteria increased the root biomass production, which resulted in higher production of root exudates increasing the beneficial bacteria, fungi and actinomycetes population in rhizosphere Panchal et al., (2018).

\section{Urease enzyme activity}

It was observed that inorganic fertilizers in combination with organic and bio-fertilizers had significant effect on urease activity of soil. The maximum urease activity $\left(221.98 \mu \mathrm{g} \mathrm{g}^{-1}\right.$ soil $\mathrm{hr}^{-1}$ ) was estimated in the treatment $\mathrm{T}_{10}$ : $80 \%$ RDF $(50 \% \mathrm{CN}+50 \%$ Urea $)+20 \% \mathrm{~N}$ $(\mathrm{VC})+$ (Azotobacter +PSB) which was statistically at par with all treatments except $\mathrm{T}_{1}, \mathrm{~T}_{2}$ and $\mathrm{T}_{3}$ during the year 2017. Whereas minimum urease activity $\left(219.16 \mu \mathrm{g} \mathrm{g}^{-1}\right.$ soil $\mathrm{hr}^{-1}$ ) was recorded in treatment $\mathrm{T}_{1}: 100 \% \mathrm{RDF}$ $(100 \% \mathrm{~N}$ through $\mathrm{CN})$ which was statistically at par with $\mathrm{T}_{2}$ and $\mathrm{T}_{3}$.

In case of second year, the maximum urease activity (222.11 $\mathrm{g} \mathrm{g} \mathrm{g}^{-1}$ soil $\left.\mathrm{hr}^{-1}\right)$ was estimated in the treatment $\mathrm{T}_{10}: 80 \% \mathrm{RDF}(50 \% \mathrm{CN}+$ $50 \%$ Urea) $+20 \% \mathrm{~N}$ (VC) + (Azotobacter +PSB) which was statistically at par with $\mathrm{T}_{3}$, $\mathrm{T}_{6}, \mathrm{~T}_{7}, \mathrm{~T}_{8}, \mathrm{~T}_{9}$ and $\mathrm{T}_{10}$ whereas minimum urease activity $\left(221.12 \mu \mathrm{g} \mathrm{g}^{-1}\right.$ soil $\left.\mathrm{hr}^{-1}\right)$ was recorded in treatment $\mathrm{T}_{1}: 100 \% \mathrm{RDF}(100 \% \mathrm{~N}$ through $\mathrm{CN}$ ) which was statistically at par with $\mathrm{T}_{4}$ and $\mathrm{T}_{5}$.

The present results are in harmony with the findings of $\mathrm{Uz}$ and Tavali, (2014) have detected a slight but statistically significant differences in urease activity of soil by using organic amendments like FYM and vermicompost as compared to control. Incorporation of organic manures influenced soil enzyme activity either because of the composition added materials themselves or because they increased microbial activity of soil Verma et al., (2018). Higher urease activity probably resulted from an increase in soil organic matter content and microbial population resulting in the secretion of urease, although no urea was applied Chang et al., (2007).

Application of different sources of nutrients had significant effect on dehydrogenase activity of soil. The maximum $\left(2.79 \mu \mathrm{g} \mathrm{g}^{-1}\right.$ soil $\mathrm{hr}^{-1}$ in the year 2017) was observed in $\mathrm{T}_{9}: 80 \%$ $\mathrm{RDF}(25 \% \mathrm{CN}+75 \%$ Urea $)+20 \% \mathrm{~N}(\mathrm{VC})+$ (Azotobacter $+\mathrm{PSB})$ which was statistically at 
par with $\mathrm{T}_{10}$ and $\mathrm{T}_{11}$. The minimum dehydroginase activity $\left(1.27 \mu \mathrm{g} \mathrm{g}^{-1}\right.$ soil $\mathrm{hr}^{-1}$ in the year 2017) was obtained in $\mathrm{T}_{4}: 100 \% \mathrm{RDF}$ $(50 \% \mathrm{CN}+50 \%$ Urea $)+($ Azotobacter $+\mathrm{PSB})$ which was statistically at par with $\mathrm{T}_{1}, \mathrm{~T}_{3}, \mathrm{~T}_{2}$, $\mathrm{T}_{5}, \mathrm{~T}_{6}$ and $\mathrm{T}_{8}$.

Data collected in the year, 2018 had also significant value on dehydrogenase activity of soil. The highest dehydrogenase activity (2.77 $\mu \mathrm{g} \mathrm{g}^{-1}$ soil $\mathrm{hr}^{-1}$ ) was observed in $\mathrm{T}_{9}: 80 \% \mathrm{RDF}$ $(25 \% \mathrm{CN}+75 \%$ Urea $)+20 \% \mathrm{~N}(\mathrm{VC})+$ (Azotobacter + PSB) which was statistically at par with $\mathrm{T}_{8}$. Whereas minimum $\left(1.32 \mu \mathrm{g} \mathrm{g} \mathrm{g}^{-1}\right.$ soil $\mathrm{hr}^{-1}$ ) was observed in $\mathrm{T}_{1}: 100 \% \mathrm{RDF}$ $(100 \% \mathrm{~N}$ through $\mathrm{CN})$.

According to Adak et al., (2014) dehydrogenase enzyme activity was augmented with soil application of $10 \mathrm{Kg}$ vermicompost $\quad+\quad \mathrm{N}: \mathrm{P}: \mathrm{K} \quad(100: 50: 100$ g/tree/year of age)+ Azotobacter +PSM+ Tricoderma harzianum + Organic mulching. Dehydrogenase activity is influenced more by the quality than quantity of organic matter incorporated into soil. Vandana et al., (2012) reported that the effect of nutrient management on enzyme activity on acid phosphatase was increased with a range from (15.5- $130.7 \mu \mathrm{g}$ of 4-nitrophenol g $\mathrm{g}^{-1}$ soil $^{-1}$ ) and alkaline phosphatase activity from (17.2 $50.3 \mu \mathrm{g}$ of 4-nitrophenol $\mathrm{g}^{-1}$ soil $\mathrm{h}^{-1}$ ). The results on dehydrogenase activity of soil of the present was fit with the findings of $\mathrm{Uz}$ and Tavali (2014) reported that in plants receiving organic material started increase in dehydrogenase activity after one month of the experiment and then decreased to control level at around three months. Elevated dehydrogenase activity is possibly due to utilization of nutrients provided by the organic materials by microorganisms resulting in an increase in microbial activity.

\section{Alkaline phosphotase}

The data related to alkaline phosphatase activity of soil observed after harvest were presented in Table 2 results revealed that alkaline phosphatase activity indicated that there was significant influence by different treatments over control. The highest alkaline phosphotase activity $\left(9.67 \mu \mathrm{g} \mathrm{g}^{-1}\right.$ soil $\left.\mathrm{hr}^{-1}\right)$ was found in $\mathrm{T}_{10}: 80 \% \mathrm{RDF}(50 \% \mathrm{CN}+50 \%$ Urea $)+20 \% \mathrm{~N}(\mathrm{VC})+($ Azotobacter $+\mathrm{PSB})$ which was at par with $\mathrm{T}_{6}, \mathrm{~T}_{7}, \mathrm{~T}_{8}, \mathrm{~T}_{9}$ and $\mathrm{T}_{11}$ whereas the lowest alkaline phosphotase activity $\left(6.97 \mu \mathrm{g} \mathrm{g}^{-1}\right.$ soil $\left.\mathrm{hr}^{-1}\right)$ was recorded in $\mathrm{T}_{3}: 100 \% \mathrm{RDF}(25 \% \mathrm{CN}+75 \%$ Urea $)+$ (Azotobacter + PSB). However, it was at par with $\mathrm{T}_{1}, \mathrm{~T}_{2}, \mathrm{~T}_{4}$ and $\mathrm{T}_{5}$ during the year 2017 . In the second year of study the highest alkaline phosphotase activity $\left(19.40 \mu \mathrm{g} \mathrm{g}^{-1}\right.$ soil $^{-1}$ ) was found in $\mathrm{T}_{11}: 80 \% \mathrm{RDF}(75 \% \mathrm{CN}+25 \%$ Urea $)+20 \% \mathrm{~N}(\mathrm{VC})+$ (Azotobacter + PSB $)$ which was at par with $\mathrm{T}_{9}$ and $\mathrm{T}_{10}$, whereas the lowest alkaline phosphotase activity $(10.06 \mu \mathrm{g}$ $\mathrm{g}^{-1}$ soil $\mathrm{hr}^{-1}$ ) was recorded in $\mathrm{T}_{2}: 100 \% \mathrm{RDF}$ $(100 \% \mathrm{~N}$ through Urea) $+($ Azotobacter + PSB). However, it was at par with $\mathrm{T}_{1}, \mathrm{~T}_{3} \mathrm{~T}_{4}$, $\mathrm{T}_{5}, \mathrm{~T}_{6}, \mathrm{~T}_{7}$ and $\mathrm{T}_{8}$ during the year 2017. The results on alkaline phosphotase activity of soil presented in Table 2 showed that its activity was much higher than acid phosphotase.

Among the treatments, alkaline phosphotase activity was found to increase with application of $\mathrm{T}_{9}$, this may be due to the fact that in general, the enzyme activity in the soil is closely related to organic matter build up Bayer et al., (1993). These results were further confirmed by the findings of Robles at al. (2016) who reported increase in acid and alkaline phosphotase activity with mineral fertilizers + organic fertilizers in vitis venifera Cv. Thompson seedless. Soil phosphatase activity was strongly inhibited by inorganic phosphate. Manure can stimulate phosphatase activity by providing soil microorganisms with sources of $\mathrm{C}, \mathrm{N}$, and $\mathrm{P}$ Heidi et al., (2011). Phosphatases can also affect environmental quality following mismanagement of manure, as $\mathrm{P}$ in surface runoff is related to organic $\mathrm{P}$ content and phosphatase activity Yu et al., (2006). 
Table.1 Effect of integrated nutrient management on Azotobacter, PSB and Actinomycetes population of soil

\begin{tabular}{|c|c|c|c|c|c|c|}
\hline \multirow[t]{2}{*}{ Treatments } & \multicolumn{2}{|c|}{$\begin{array}{c}\text { Azotobacter }\left(\mathrm{CFU} \times 10^{5}\right. \\
\left.\mathrm{g}^{-1} \text { soil }\right)\end{array}$} & \multicolumn{2}{|c|}{ PSB $\left(\right.$ CFU $\times 10^{5} \mathrm{~g}^{-1}$ soil $)$} & \multicolumn{2}{|c|}{$\begin{array}{c}\text { Actinomycetes }(\mathrm{CFU} \times \\
\left.10^{4} \mathrm{~g}^{-1} \text { soil }\right)\end{array}$} \\
\hline & 2017 & 2018 & 2017 & 2018 & 2017 & 2018 \\
\hline $\mathbf{T}_{1}$ & 17.23 & 14.10 & 16.60 & 12.43 & 11.87 & 15.83 \\
\hline $\mathbf{T}_{2}$ & 18.03 & 17.66 & 18.40 & 13.23 & 11.90 & 17.33 \\
\hline $\mathbf{T}_{3}$ & 17.80 & 19.00 & 18.40 & 15.17 & 12.70 & 19.00 \\
\hline $\mathbf{T}_{4}$ & 17.56 & 13.90 & 19.63 & 18.63 & 13.93 & 17.10 \\
\hline $\mathbf{T}_{5}$ & 18.43 & 21.16 & 20.37 & 18.03 & 13.73 & 21.17 \\
\hline $\mathbf{T}_{6}$ & 18.83 & 21.40 & 21.50 & 25.37 & 13.77 & 21.40 \\
\hline $\mathbf{T}_{7}$ & 18.96 & 20.50 & 20.50 & 23.63 & 15.77 & 20.50 \\
\hline $\mathbf{T}_{8}$ & 19.00 & 22.60 & 21.67 & 20.63 & 15.97 & 22.60 \\
\hline $\mathbf{T}_{9}$ & 20.43 & 23.33 & 22.60 & 29.43 & 17.77 & 22.67 \\
\hline $\mathbf{T}_{10}$ & 19.70 & 21.23 & 22.00 & 27.63 & 18.27 & 21.23 \\
\hline $\mathbf{T}_{11}$ & 19.23 & 22.33 & 21.53 & 25.63 & 16.03 & 21.67 \\
\hline Mean & 18.65 & 19.74 & 20.29 & 20.89 & 14.70 & 20.05 \\
\hline $\mathrm{CD}_{(0.05 \%)}$ & 0.31 & 0.26 & NS & 1.43 & 1.40 & 3.40 \\
\hline
\end{tabular}

Table.2 Effect of integrated nutrient management on enzyme activities of soil

\begin{tabular}{|c|c|c|c|c|c|c|}
\hline \multirow[t]{2}{*}{ Treatments } & \multicolumn{2}{|c|}{$\begin{array}{c}\text { Urease activity }\left(\mu \mathrm{g} \mathrm{g}^{-1}\right. \\
\left.\text { soil } \mathbf{h r}^{-1}\right)\end{array}$} & \multicolumn{2}{|c|}{$\begin{array}{c}\text { Dehydrogenase activity } \\
\left(\mu \mathrm{g} \mathrm{g}^{-1} \text { soil } \mathrm{hr}^{-1}\right)\end{array}$} & \multicolumn{2}{|c|}{$\begin{array}{l}\text { Alkaline phosphotase ( } \mu \mathrm{g} \\
\left.\mathrm{g}^{-1} \text { soil } \mathbf{h r}^{-1}\right)\end{array}$} \\
\hline & 2017 & 2018 & 2017 & 2018 & 2017 & 2018 \\
\hline $\mathbf{T}_{1}$ & 219.16 & 221.12 & 1.29 & 1.32 & 7.23 & 10.34 \\
\hline $\mathbf{T}_{2}$ & 220.06 & 221.65 & 1.34 & 1.77 & 7.09 & 10.06 \\
\hline $\mathbf{T}_{3}$ & 219.94 & 221.71 & 1.32 & 1.54 & 6.97 & 11.81 \\
\hline $\mathbf{T}_{4}$ & 221.70 & 221.48 & 1.27 & 1.33 & 8.00 & 13.71 \\
\hline $\mathbf{T}_{5}$ & 221.75 & 221.44 & 1.31 & 1.71 & 8.07 & 12.98 \\
\hline$T_{6}$ & 221.59 & 221.95 & 1.89 & 1.47 & 8.89 & 13.88 \\
\hline $\mathbf{T}_{7}$ & 221.70 & 221.96 & 1.87 & 1.59 & 9.08 & 13.30 \\
\hline$T_{8}$ & 221.32 & 221.91 & 1.45 & 2.25 & 9.41 & 13.73 \\
\hline $\mathbf{T}_{9}$ & 221.72 & 221.92 & 2.79 & 2.77 & 9.23 & 15.51 \\
\hline$T_{10}$ & 221.98 & 222.11 & 2.36 & 1.58 & 9.67 & 16.08 \\
\hline $\mathbf{T}_{11}$ & 221.58 & 222.01 & 1.97 & 1.95 & 9.58 & 19.40 \\
\hline Mean & 221.14 & 221.75 & 1.71 & 1.75 & 8.47 & 13.71 \\
\hline$C D_{(0.05 \%)}$ & 1.04 & 0.42 & 0.88 & 0.66 & 1.57 & 4.49 \\
\hline
\end{tabular}

\section{Acknowledgement}

This research was supported by Department of Fruit Science, Dr YS parmar University of Horticulture and Forestry, nauni, Solan (H.P). I would like to express my great appreciation to Dr. D D Sharma for assistance in this research programme.

\section{References}

Beyer, L., Wachendorf, C. Elsner, C. and Knabe, R.1993. Suitability of dehydrogenase activity assay as an index of soil biological activity. Biology and Fertility of Soils. 16: 52-56. 
Casida, L.E., D.A Klein and Santoro, T. 1964. Soil dehydrogenase activity. Soil Science. 98: 371-376.

Chang, E.H., R.S Chung and Tsai, Y.H. 2007. Effect of different application rates of organic fertilizer on soil enzyme activity and microbial population. Soil Science and Plant Nutrition. 53: 132 140

Das, S.K., and Varma, A. 2011. Role of enzyme in maintaining soil health. In: Soil enzymology (ed.) Shukla, G., and Varma, A. Springer Heidelberg Dordrecht London, New York. Pp. 26.

Debnath, S., A.K Patra, N. Ahmed, S. Kumar and Dwivedi, B.S. 2015. Assessment of microbial biomass and enzyme activities in soil under temperate fruit crops in north western himalayan region. Journal of Soil Science and Plant Nutrition, 15 (4): 848-866.

Dhingra, O.D., and Sinclair, J.B. 2000. Basic plant pathology methods. CEC press, London. pp. 122-125

Edwards, C.A., 1998. The use of earthworms in the breakdown and management of organic wastes. In: Earthworm Ecology, CRC Press LLC, Boca Raton, Fl, pp 327-354

Khare, N., D.V. Pathak and Kumar, M. 2018. Microbially enriched vermicompost affecting seedling and plant growth in aonla and bael. International Journal of Current Microbiology and applied Sciences. 7(4): 2664-2672.

Kuma, V., J. Saikia, N. Barik and Das, T. 2017. Effect of Integrated Nutrient Management on Soil Enzymes, Microbial Biomass Carbon and Microbial Population under Okra Cultivation. International Journal of Biochemistry Research \& Review. 20(4): 1-7.

Laishram, N., S.R. Dhimam, Y.C. Gupta, S.K. Bhardwaj and Singh, A. 2013. Microbial dynamics and physico- chemical properties of soil in the rhizosphere of chrysanthemum (Dandranthema grandiflora) as influenced by integrated nutrient management. Indian Journal of Agricultural Sciences. 83 (4): 447-455.

Lu, C., and Tain, H. 2017. Global nitrogen and phosphorus fertilizers used for agriculture production in the past half century: shifted hot spots and nutrient imbalance, Earth System Science Data. 9:181-192.

Martin, J.P. 1950. Use of acid rose Bengal and streptomycin in the plate method for estimating soil fungi. Soil Science. 69: 215-232.

Panchal, B.H., V.K. Patel, K.P. Patel and Khimani, RA. 2018. Effect of biofertilizers, organic manures and chemical fertilizers on microbial population, yield and yield attributes and quality of Sweet corn (Zeya mays L. saccharata) cv. Madhuri. International Journal of Current Microbiology and Applied Sciences. 7(9): 2423-2431.

Singh, K.K., S. Barche and Singh, DB. 2010. Integrated nutrient management in papaya (Carica papaya L.) cv. Surya. Acta Horiculturae. 851: 377-380.

Sinha, R. Heart, S. Valani, D Chauhan and Kumar, K. 2009. Earthworms Vermicompost: A powerful crop nutrient over the convention compost \& protective soil conditioner against the Destructive Chemical fertilizers for Food Safety and Security. AmericanEurasian Journal of Agricultural and Environmental Scienc., 5: 01-55.

Tabatabai, M.A., and Bremner, J.M. 1969. Use of P-nitrophenyl phosphate for assay of soil phosphate activity. Soil Biology and Biochemistry. 1: 301-307

Tabatabi, M.A., and Bremner, J.M. 1972. Assay of urease activity in soils. Soil Biology and Biochemistry. 4: 479-487. 
Uz, I., and Tavali, I.E. 2014. Short-Term Effect of Vermicompost Application on Biological Properties of an Alkaline Soil with High Lime Content from Mediterranean Region of Turkey. Scientific World Journal. p.11.

Vandana, L.J., P.C, Rao and Padmaja, G. 2012. Effect of herbicides and nutrient management on soil enzyme activity. Journal of Rice Research. 5 (1 \& 2): 5058.

Verma, S.N., M. Sharma and Urmila. 2018. Effect of INM on Soil Microbial
Biomass Carbon and Enzyme Activity under Soybean of a Typic haplustepts. International Journal of Current Microbiology and Applied Science. 7(1): 1312-1318.

Wang, Z., G. Xu, P. Ma, Y. Lin, Z. Yang and Cao, C. 2017. Isolation and characterization of phosphorus solubilizing bacteria from the rhizosphere. Soil and its Colonization of Chinese Cabbage (Brassica campestris ssp. chinensis). Frontiers in Microbiology. 8: 1270.

\section{How to cite this article:}

Kuchay, M.A., Sharma, D.D. and Vijay Kumar. 2019. Evaluation of Microbial and Enzyme Activity of Rhizospheric Soils under Integrated Nutrient Management of Apricot. Int.J.Curr.Microbiol.App.Sci. 8(11): 2381-2389. doi: https://doi.org/10.20546/ijcmas.2019.811.276 